\title{
A korszerü sugárterápiás kezelések mellékhatásainak metaanalízise prosztatarákos betegeknél
}

\author{
Zemplényi Antal Tamás ${ }^{1,4}$ - Mangel László dr. ${ }^{2}$ - Kaló Zoltán dr. ${ }^{6,7}$ \\ Endrei Dóra dr. ${ }^{3,4}$ - Lohner Szimonetta dr. ${ }^{5}$. Boncz Imre dr. ${ }^{4}$ \\ Pécsi Tudományegyetem, ${ }^{1}$ Kancellária, Egészségügyi Gazdálkodási Igazgatóság, ${ }^{2}$ Általános Orvostudományi Kar, \\ Klinikai Központ, Onkoterápiás Intézet, ${ }^{3}$ Általános Orvostudományi Kar, Klinikai Központ, \\ ${ }^{4}$ Egészségtudományi Kar, Egészségbiztosítási Intézet, ${ }^{5}$ Klinikai Központ, Cochrane Hungary, Pécs \\ ${ }^{6}$ Eötvös Loránd Tudományegyetem, Egészség-gazdaságtani Kutatóközpont, Budapest \\ ${ }^{7}$ Syreon Kutató Intézet, Budapest
}

Bevezetés: A sugárterápia technológiai fejlődésének egyik célterülete a prosztatarák megfelelő sugaras ellátása. Célkitüzés: Az elemzés célja a normálfrakcionálású és a hipofrakcionált, illetve a konvencionális és a magas dózisú intenzitásmodulált sugárterápia biztonságosságának vizsgálata. Módszer: A sugárkezelés szövődményeinek gyakoriságát metaanalízissel elemezték. Eredmények: Magasabb dózisú intenzitásmodulált sugárterápiával sem a súlyos urogenitalis (akut: $\mathrm{p}=0,9$, késői: $\mathrm{p}=0,95$ ), sem a mérsékelt vagy súlyos gastrointestinalis (akut: N/A, késői: $\mathrm{p}=0,08$ ) mellékhatásokban nincs eltérés a hagyományos besugárzási eljárásokhoz képest. A mérsékelt akut (relatív kockázat = 1,39, 95\%-os konfidenciaintervallum: 1,09-1,78, p =0,008) és késői (relatív kockázat $=1,48,95 \%$-os konfidenciaintervallum: 1,26-1,75, p<0,00001) urogenitalis mellékhatások relatív kockázata magasabb. A hipofrakcionált besugárzás súlyos urogenitalis (akut: $\mathrm{N} / \mathrm{A}$, késői: $\mathrm{p}=0,73$ ) és mérsékelt vagy súlyos gastrointestinalis (akut $\mathrm{p}=0,73$, késői $\mathrm{p}=0,55)$ mellékhatásrátája sem tér el a normálfrakcionálású kezeléstől, azonban a mérsékelt késői urogenitalis mellékhatás kockázata magasabb (relatív kockázat = 1,39, 95\%-os konfidenciaintervallum: 1,00-1,94,p = 0,05). Következtetések: Intenzitásmodulált sugártervezés és képvezérelt kezeléskiszolgáltatás mellett a hipofrakcionált és az emelt dózisú protokoll egyaránt biztonságos. Orv. Hetil., 2016, 157(20), 776-788.

Kulcsszavak: prosztatarák, sugárterápia, hipofrakcionálás, metaanalízis

\section{Meta-analysis of the side-effect profiles of modern radiation therapies for patients with prostate cancer}

Introduction: One of the most relevant focus of recent developments in radiotherapy technology was the adequate irradiation of prostate cancer. Aim: The aim of this study was to analyse the safety of normo- and hypofractionated and high dose intensity-modulated radiotherapy. Method: Toxicities were identified through literature review and evidence was synthetized with meta-analytical methods. Results: The use of high dose intensity-modulated radiotherapy resulted in no difference in severe genitourinary (acute $\mathrm{p}=0.9$; late $\mathrm{p}=0.95$ ) and moderate or severe gastrointestinal (acute: $\mathrm{N} / \mathrm{A}$; late: $\mathrm{p}=0.08$ ) toxicities compared to $3 \mathrm{D}$ conformal radiation therapy. The risk ratio of moderate acute $(\mathrm{RR}=1.39,95 \% \mathrm{CI}: 1.09-1.78 ; \mathrm{p}=0.008)$ and late genitourinary toxicities $(\mathrm{RR}=1.48,95 \% \mathrm{CI}$ : 1.26-1.75; $\mathrm{p}<0,00001)$ was higher. There was no difference in hypo- and normofractionated intensity-modulated radiotherapy regarding severe genitourinary (acute: $\mathrm{N} / \mathrm{A}$; late: $\mathrm{p}=0.73$ ) and moderate or severe gastrointestinal (acute: $\mathrm{p}=0.73$; late: $\mathrm{p}=0.55$ ) toxicities, the risk of late moderate genitourinary toxicities was higher when using hypofractionation scheme $(\mathrm{RR}=1.39,95 \% \mathrm{CI}: 1.00-1.94 ; \mathrm{p}=0.05)$. Conclusions: The use of normo- and hypofractionated and high dose intensity-modulated radiotherapy proved to be safe. However the higher risk of moderate genitourinary adverse events require an extensive clinical risk estimation.

Keywords: prostatic neoplasm, radiotherapy, dose hypofractionation, meta-analysis

Zemplényi, A. T., Mangel, L., Kaló, Z., Endrei, D., Lohner, Sz., Boncz, I. [Meta-analysis of the side-effect profiles of modern radiation therapies for patients with prostate cancer]. Orv. Hetil., 2016, 157(20), 776-788.

(Beérkezett: 2016. február 14.; elfogadva: 2016. március 17.) 


\section{Rövidítések}

$3 \mathrm{D}=$ háromdimenziós; 3DCRT $=(3 \mathrm{D}$ conformal radiation therapy) háromdimenziós konformális sugárterápia; $\mathrm{BED}=$ (biological equivalent dose) biológiailag egyenértékû dózis; $\mathrm{CI}=$ konfidenciaintervallum; HF-IMRT $=$ (hypofractionated intensity-modulated radiotherapy) hipofrakcionált intenzitásmodulált sugárterápia; IGRT = (image-guided radiotherapy) képvezérelt sugárterápia; IMRT = (intensity-modulated radiotherapy) intenzitásmodulált sugárterápia; $R R=$ (relative risk $)$ relatív kockázat

A prosztatarák világszerte a férfi lakosság leggyakoribb és típusos daganatos megbetegedése. 2012-ben a világon mintegy 1,1 millió új esetet diagnosztizáltak, ami a férfiak daganatos megbetegedéseinek mintegy 15\%-át teszi ki [1]. A nyugati világ legtöbb országában a férfiaknál ez a leggyakoribb daganat, a világ minden országát figyelembe véve a tüdőrák után ez a második leggyakoribb daganatos halálok. Az új esetek száma éves szinten a becsült adatok szerint az Egyesült Államokban körülbelül 250 ezer [2], Európában mintegy 350 ezer [3], Magyarországon megközelítőleg 4000 [4].

A lokalizált prosztatarák gyógyításának elfogadott formája a definitív sugárkezelés. Az is közismert, hogy a jellegzetes prosztataráktípus, az adenocarcinoma szövettani és biológiai jellegzetességei miatt a tartós lokális kontroll eléréséhez magas sugárterápiás dózisok kiszolgáltatására van szükség. Így ebben a daganatos betegségben a sugárterápiás dóziseszkalációnak egyértelmú hatása van a betegség lefolyására, a biokémiai vagy klinikai progresszió késleltetésére és végső soron a teljes túlélés növelésére [5]. A tartós lokális tumorkontroll eléréséhez számtalan szerző javaslata alapján igen magas, 80 Gy körüli dózis kiszolgáltatása szükséges, ezen dózistartomány elérésének igénye pedig már az elmúlt évtizedben óhatatlanul megkövetelte a legkorszerúbb besugárzási technikák alkalmazását. Egy más szempontból tekintve a technológiai fejlődés alkalmazásának egyik legfontosabb területe éppen a prosztatarák megfelelő sugaras ellátása volt, hiszen a modern technológia sokkal inkább biztosítja a magas dózistartomány okozta sugárterápiás szövődmények elkerülését. Az elmúlt években számtalan közlemény foglalkozott a prosztatadaganatok korszerú sugárkezelésének lehetőségeivel [6-9], például az úgynevezett intenzitásmodulált radioterápia (IMRT) egyik leggyakoribb alkalmazási területe éppen a lokalizált prosztatarák ellátása. Természetes, hogy mindezek alapján jogos az igény, hogy a fejlődés eredményeit mindenhol, így Magyarországon is, tudjuk biztosítani a betegek számára [10].

Egyébiránt a sugárterápia már több mint százéves gyógyító célú felhasználása mellett mindig is alapvető szempont volt a súlyos mellékhatások elkerülése. Éppen ezért a klinikai alkalmazás és a dózismeghatározás elsődleges limitáló tényezője a nemkívánatos szövődmények esélyének minimális szinten tartása volt, sokszor és akár a kívánatos effektus rovására is. Éppen ezért a modern technológia birtokában szintén rendkívül fontos a mellékhatások kialakulási valószínúségének ismerete, hiszen a klinikai területen csak így van jogalapja egy újabb kezelési eljárás bevezetésének. Munkánk célja éppen az, hogy irodalmi ismeretek alapján felmérjük az újabb sugárterápiás módszerek mellékhatás-gyakoriságát és -profilját, ezzel is kiegészítve az előzetes, hatásossággal és költséghatékonysággal foglalkozó közleményeink értékét [11, 12].

Jelen referátumunkban azt kívánjuk megvizsgálni, hogy a korszerú és dózisemeléssel alkalmazott IMRT miként befolyásolja a mellékhatások kialakulásának valószínűségét. Másik lehetőségként szintén elemezzük egy modern technológiát felhasználó kezelési metódus, a rövidített, úgynevezett hipofrakcionált IMRT (HF-IMRT) mellékhatásait. Említést érdemel, hogy a prosztataadenocarcinoma biológiai sajátossága az alacsony alfa/béta hányados, ami a magasabb napi frakciók előnyösebb sugárbiológiai hatását jelzi előre [13-17]. E magasabb napi dózisok kiszolgáltatása azonban fooleg a késői megjelenésư normális szöveti toxicitás magasabb esélyét is magával vonja. A HF ezért csak modern technológia (IMRT, IGRT) mellett alkalmazható, de mindennek a birtokában a HF-IMRT - hasonló hatékonysággal és nem magasabb toxicitással - közel felére rövidítheti a teljes kezelési kurzust, valamennyire kompenzálva a magasabb bekerülési költségeket, humán erőforrás- és munkaidőigényt. Korábbi közleményeinkben az alkalmazott sugárterápiás módszerek költségeit és költséghatékonyságát már vizsgáltuk $[11,12,18]$. Jelen elemzésünk célja a dóziseszkaláció és a hipofrakcionált besugárzási módszer alkalmazása esetén kialakuló mellékhatások valószínüségének vizsgálata metaanalízis módszerével.

\section{Módszer}

A lokalizált prosztatarákos betegek 3DCRT-vel (háromdimenziós konformális sugárterápiával) vagy IMRT-vel történő sugárkezelésének mellékhatásrátáját átfogó irodalomkutatás útján határoztuk meg. Az irodalomkeresési stratégia a következő elemeket foglalta magában: a releváns szisztematikus irodalmi áttekintések hivatkozásainak vizsgálata, adatbázis-keresés és a területen illetékes szakértőkkel történő konzultáció. Az adatbázis-keresést a Medline és a Scopus adatbázisokon hajtottuk végre 2005 és 2014 közötti időszakra vonatkozóan. Az irodalomkeresés 2014 augusztusában történt, ami 2015 szeptemberében 2014. december 31-ei dátummal frissítésre került.

A tudományos bizonyítékok hierarchiáját figyelembe véve elsődlegesen randomizált, kontrollált (randomized controlled trial - RCT) vizsgálatokat és szisztematikus irodalmi áttekintésekre épülő metaanalíziseket kerestünk, mivel ezek tekinthetők a bizonyítékokra épülő elemzések szempontjából a leginkább irányadónak [19]. RCT-k hiányában ugyanakkor figyelembe vettünk kohorsz- vagy eset-kontroll vizsgálatokat is. 
Az elemzésünk fókuszában lévő vizsgált technológia a normálfrakcionálású és hipofrakcionált magas dózisú intenzitásmodulált sugárterápia (IGRT-vel vagy a nélkül). A normálfrakcionálású IMRT komparátora a hagyományos dózisú háromdimenziós konformális sugárterápia. Magyarországon eddig ez volt tekinthető a lokalizált prosztatarákos betegek ellátása szempontjából rutinszerüen alkalmazott sugárterápiás módszernek. A frakcionálás új megközelítésével végzett sugárkezelés komparátora elemzésünkben a normálfrakcionálású IMRT. Olyan lokalizált prosztatarákos betegekre vonatkozó irodalmi adatokat vizsgáltunk, akik számára a kuratív sugárterápia megfelelő kezelési alternatívát kínált. Az elemzés szempontjából vizsgált kimenetel az akut és késői kezelési szövődmény, mellékhatás.

A nem angol nyelven publikált közleményeket nem vettük figyelembe. A prosztatadaganat mütéti eljárással történő kezelése, az extrém hipofrakcionálású stereotaxiás sugárkezelés (stereotactic body radiation therapy SBRT), a közelterápiás lehetőségek (brachytherapia, cryotherapia), a beavatkozással nem járó módszerek (watchful waiting, active surveillance), illetve a kizárólag hormonterápiával történő kezelések nem képezték az elemzés tárgyát. Figyelmen kívül hagytuk továbbá a kizárólag tervezésre, dózisszámításra és céltérfogat-meghatározásra irányuló közleményeket, illetve a komparátor nélküli klinikai vizsgálatokat.

A feldolgozott közlemények adatai között figyelembe vettük, hogy mekkora volt a sugárkezelés során leadott dózis kumulatív mennyisége a klinikai vizsgálat során (hagyományos vagy magas dózisú), és hogy milyen frakcionálási sémát alkalmaztak (normál- vagy mérsékelt hipofrakcionálás). Ez lehetővé tette, hogy az adatok további feldolgozását azokra a komparatív klinikai vizsgála-

\section{Szisztematikus irodalmi áttekintések szürése}

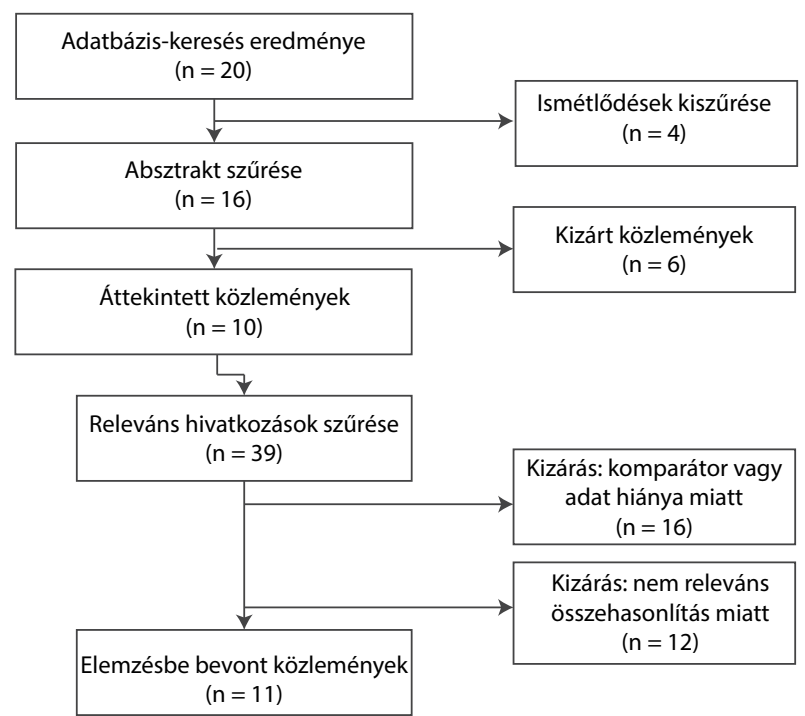

tokra szúkítsük, amelyek esetében a vizsgált terápiás technikák az elemzésünk szempontjából relevánsak voltak. Az adatok még így is heterogének voltak például a céltérfogat meghatározásának eltérő módszerei, illetve a betegpozicionálás és a képvezérelt besugárzási technika alkalmazási gyakorlatának különbözőségei miatt.

Az adatokat a Review Manager 5.3 statisztikai szoftverrel dolgoztuk fel [20] metaanalízis módszerével. Az elemzésben a különböző sugárterápiás kezelési módszerek alkalmazása során kialakuló mellékhatások relatív kockázatát (risk ratio - RR) határoztuk meg [21], 95\%os megbízhatósági szintet (konfidenciaintervallum), illetve $5 \%$ alatti $p$-értéket $(\mathrm{p}<0,05)$ figyelembe véve. A heterogenitás elemzéséhez az $\mathrm{I}^{2}$ módszerét alkalmaztuk, ahol 25\%-ig alacsony szintü, 25-50\% között mérsékelt, míg 50\% felett nagyfokú heterogenitást feltételeztünk [22]. A klinikai vizsgálatokban a sugárkezelések egyes jellemzőinek eltérősége miatt (például céltérfogat meghatározása, előzetes hormonterápia alkalmazása, IGRT használata stb.) az elemzésben randomhatás-modellt alkalmaztunk [23].

\section{Eredmények}

A szisztematikus és egyéb irodalmi áttekintésekre vonatkozó adatbázis-keresés eredményeként az ismétlődések kiszürése és az absztrakt-felülvizsgálatot követően 10 olyan közleményt azonosítottunk (1.ábra), amelyeknek a referenciáit részletesen megvizsgáltuk. Ezek közül hat közlemény [24-29] foglalkozott az intenzitásmodulált sugárterápiával és négy [30-33] a hipofrakcionált sugárterápia klinikai adataival.

A hivatkozott 39 releváns közlemény közül 11-et vettünk figyelembe az elemzésben. A publikált szisztemati-

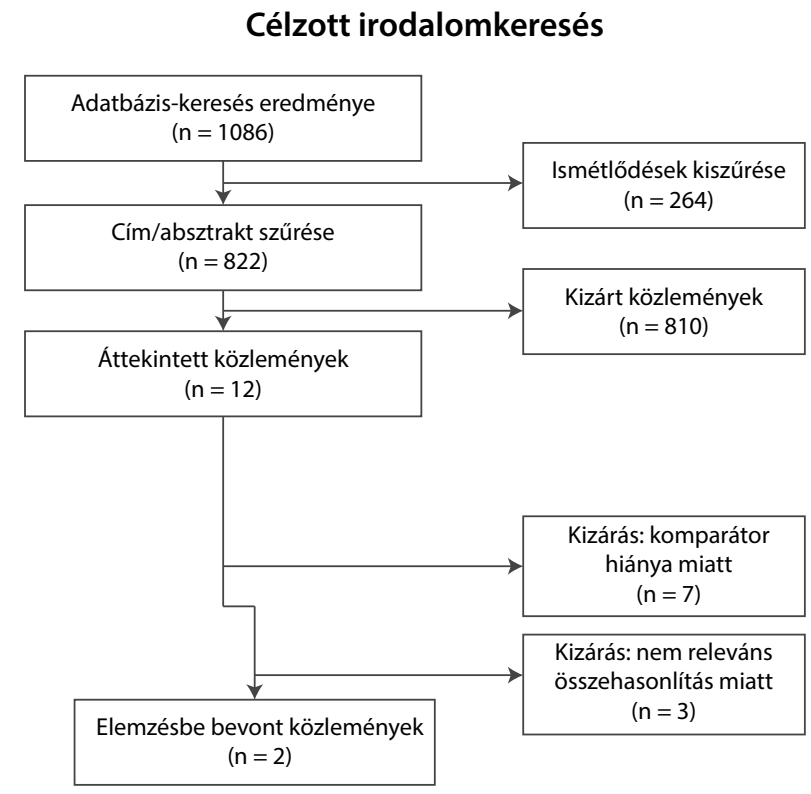

1. ábra

A hagyományos dózisú 3DCRT és a magas dózisú IMRT/HF-IMRT sugártoxicitása szempontjából releváns közlemények azonosítása szisztematikus irodalmi áttekintések szürése és célzott irodalomkeresés alapján 
kus áttekintésekből esetlegesen kimaradó vagy azt követően megjelent közlemények azonosítása érdekében elvégzett második adatbázis-keresés során 1086 közleményt azonosítottunk. Az ismétlődések törlése és a cím, illetve absztrakt áttekintésével végzett szürést követően 12 cikket néztünk át, amelyek közül mindössze kettőt tudtunk az elemzésben figyelembe venni. A két adatbázis-keresés eredményeként az első körben azonosított 39, illetve 12 közlemény esetében a további kizárás oka a komparátor hiánya vagy az összehasonlított sugárterápiás technikák egyéb lényeges paramétereinek különbözősége volt. Az előbbi kizárási ok, a komparátor hiánya a publikált klinikai vizsgálatokban egyértelműen azonosítható. A sugárkezelés hatásosságát bemutató összehasonlító vizsgálatok esetében azonban további paramétereket is elemeztünk, mint a sugárterápiás technika, a teljes leadott dózis erőssége, illetve a frakcionálás típusa (1. és 2. táblázat). A klinikai vizsgálatok áttekintése során az elemzés szempontjából releváns vizsgálatok kiválasztásához két vagylagos feltételt határoztunk meg:

- hagyományos dóziserősségű sugárterápiát hasonlítson össze magas dózisú IMRT-vel végzett sugárkezeléssel, vagy

- hipofrakcionálással végzett sugárkezelést hasonlítson össze normálfrakcionálású kezeléssel magas sugárdózis elérése mellett.

Magas sugárdózis alatt a 75-80 Gy körüli teljes (BEDszámolás alapján) sugárterápiás dózist, míg hipofrakcio- nálás alatt jelen esetben a 30 vagy az alatti frakciószámú, alkalmanként 2,5-4 Gy közötti dóziserősségű kezelést értjük. A további elemzéshez azért ezt a két szempontot vettük figyelembe, mert arra voltunk kíváncsiak, hogy a magas sugárdózis esetén az IMRT mennyire biztonságos, vagyis mekkora a mellékhatások kialakulásának valószínűsége. A másik vizsgálandó kérdés az volt, hogy a frakciók számának csökkentése és az egyszeri dóziskiszolgálások erejének növelése a biológiai szempontból megegyezőnek tekinthető teljes dóziserősség mellett növeli-e a mellékhatások kialakulásának kockázatát.

\section{A sugártoxicitások elemzése metaanalizissel}

A mellékhatások felmérésére a figyelembe vett közlemények az RTOG (Radiation Therapy Oncology Group) vagy NCI-CTC (National Cancer Institute - Common Toxicity Criteria) rendszert használták, ahol a mellékhatások súlyosságát 1-től 5-ig terjedő skálán értékelik. 1 jelenti az enyhe tüneteket, míg 5 a halált. A közlemények elsősorban a grade 2 vagy annál súlyosabb urogenitalis és gastrointestinalis mellékhatásokat vizsgálták akut (a sugárterápia során kialakuló) és késői (krónikus) megjelenési formában. A szexuális diszfunkcióra vonatkozóan az elemzés szempontjából releváns összehasonlító vizsgálatot nem találtunk.

1. táblázat | A hagyományos dózisú 3DCRT és magas dózisú IMRT alkalmazása esetén kialakuló sugártoxicitásokat vizsgáló közlemények adatai

\begin{tabular}{|c|c|c|c|c|c|c|c|c|c|c|c|c|c|c|}
\hline Közlemény & $\begin{array}{l}\text { Teljes dózis } \\
\text { (Gy) }\end{array}$ & $\begin{array}{l}\text { Dózis- } \\
\text { kategó- } \\
\text { ria }\end{array}$ & $\begin{array}{l}\text { Sugár- } \\
\text { terápiás } \\
\text { technika }\end{array}$ & $\mathrm{n}$ & $\begin{array}{l}\text { Toxicitás } \\
\text { mérési } \\
\text { rendszere }\end{array}$ & $\begin{array}{l}\text { Akut } \\
\text { GI } \\
\text { Gr } \geq 2\end{array}$ & $\begin{array}{l}\text { Akut } \\
\text { GI } \\
\text { Gr } \geq 3\end{array}$ & $\begin{array}{l}\text { Akut } \\
\text { GU } \\
\text { Gr } \geq 2\end{array}$ & $\begin{array}{l}\text { Akut } \\
\text { GU } \\
\text { Gr } \geq 3\end{array}$ & $\begin{array}{l}\text { Késői } \\
\text { GI Gr } \geq 2\end{array}$ & $\begin{array}{l}\text { Késői } \\
\text { GI Gr } \geq 3\end{array}$ & $\begin{array}{l}\text { Késői } \\
\text { GU } \\
G r \geq 2\end{array}$ & $\begin{array}{l}\text { Késői } \\
\text { GU } \\
\text { Gr } \geq 3\end{array}$ & $\begin{array}{l}\text { Után- } \\
\text { köve- } \\
\text { tés, év }\end{array}$ \\
\hline \multirow{2}{*}{$\begin{array}{l}\text { Kirichenko, } \\
\text { et al. (2006) }\end{array}$} & 72 Gy & Hagy. & 3DCRT & 928 & $N A$ & - & - & - & - & $10 \%$ & - & $6 \%$ & - & 3 \\
\hline & 78 Gy & Magas & IMRT & 489 & & - & - & - & - & $6 \%$ & - & $8 \%$ & - & 3 \\
\hline Szignifikancia & & & & & & & & & & $p=0,009$ & & $N S z$ & & \\
\hline \multirow{2}{*}{$\begin{array}{l}\text { Vora, et al. } \\
(2007)\end{array}$} & 68,4 Gy & Hagy. & 3DCRT & 271 & RTOG & $54 \%$ & $0 \%$ & $40 \%$ & $1 \%$ & $16 \%$ & $2 \%$ & $21 \%$ & $5 \%$ & 5 \\
\hline & $75,6 \mathrm{~Gy}$ & Magas & IMRT & 145 & & $50 \%$ & $1 \%$ & $49 \%$ & $3 \%$ & $24 \%$ & $1 \%$ & $28 \%$ & $6 \%$ & 5 \\
\hline Szignifikancia & & & & & & $N S z$ & $N S z$ & $N S z$ & $N S z$ & $N S z$ & $N S z$ & $N S z$ & $N S z$ & \\
\hline \multirow{3}{*}{$\begin{array}{l}\text { Zelefsky, et al. } \\
(2008)\end{array}$} & $66-75,6$ & Hagy. & 3DCRT & 830 & NCI & $1 \%$ & - & $22 \%$ & - & $13 \%$ & $1 \%$ & $12 \%$ & $3 \%$ & 10 \\
\hline & & & & & СТC 3.0 & & & & & & & & & \\
\hline & 81 Gy & Magas & IMRT & 741 & & $3 \%$ & - & $37 \%$ & - & $5 \%$ & $1 \%$ & $20 \%$ & $3 \%$ & 10 \\
\hline Szignifikancia & & & & & & $p=0$, & & $p=0$ & & $p<0,001$ & & $p=0, c$ & & \\
\hline \multirow{3}{*}{$\begin{array}{l}\text { Doležel, et al. } \\
(2010)\end{array}$} & 74 Gy & Hagy. & 3DCRT & 94 & RTOG & $35 \%$ & $0 \%$ & $27 \%$ & $17 \%$ & $32 \%$ & $14 \%$ & $14 \%$ & $9 \%$ & 3 \\
\hline & $78 \mathrm{~Gy}$ & Magas & IMRT & 138 & & $16 \%$ & $0 \%$ & $33 \%$ & $13 \%$ & $19 \%$ & $5 \%$ & $13 \%$ & $7 \%$ & 3 \\
\hline & 82 Gy & Magas & IMRT & 52 & & $8 \%$ & $0 \%$ & $31 \%$ & $8 \%$ & $26 \%$ & $2 \%$ & $17 \%$ & $6 \%$ & 3 \\
\hline Szignifikancia & & & & & & $N A$ & $N A$ & $N A$ & $N A$ & $N S z$ & $p=0,02$ & $N S z$ & $N S z$ & \\
\hline
\end{tabular}

3DCRT = háromdimenziós konformális sugárterápia; GI = gastrointestinalis toxicitás; Gr = grade; GU = urogenitalis toxicitás; Gy = Gray; IMRT = intenzitásmodulált sugárterápia; NA = nincs adat; NCI CTC 3.0 = National Cancer Institute Common Toxicity Criterea version 3.0; $\mathrm{NSz}=$ nem szignifikáns; hagy. = hagyományos; RTOG = Radiation Therapy Oncology Group. 
2. táblázat |A normo- és hipofrakcionált IMRT alkalmazása esetén kialakuló sugártoxicitásokat vizsgáló közlemények adatai

\begin{tabular}{|c|c|c|c|c|c|c|c|c|c|c|c|c|c|c|}
\hline Közlemény & $\begin{array}{l}\text { Teljes dózis } \\
\text { (Gy) }\end{array}$ & $\begin{array}{l}\text { Dózis/ } \\
\text { frakció }\end{array}$ & $\begin{array}{l}\text { Frakciók } \\
\text { száma }\end{array}$ & $\mathrm{n}$ & $\begin{array}{l}\text { Toxicitás } \\
\text { mérési } \\
\text { rendszere }\end{array}$ & $\begin{array}{l}\text { Akut } \\
\text { GI } \\
\text { Gr } \geq 2\end{array}$ & $\begin{array}{l}\text { Akut } \\
\text { GI } \\
G r \geq 3\end{array}$ & $\begin{array}{l}\text { Akut } \\
\text { GU } \\
\text { Gr } \geq 2\end{array}$ & $\begin{array}{l}\text { Akut } \\
\text { GU } \\
\text { Gr } \geq 3\end{array}$ & $\begin{array}{l}\text { Késői } \\
\text { GI Gr } \geq 2\end{array}$ & $\begin{array}{l}\text { Késői } \\
\text { GI } \\
\text { Gr } \geq 3\end{array}$ & $\begin{array}{l}\text { Késői } \\
\text { GU } \\
G r \geq 2\end{array}$ & $\begin{array}{l}\text { Késői } \\
\text { GU } \\
\text { Gr } \geq 3\end{array}$ & $\begin{array}{l}\text { Után- } \\
\text { köve- } \\
\text { tés, év }\end{array}$ \\
\hline \multirow{2}{*}{$\begin{array}{l}\text { Arcangeli, } \\
\text { et al. }(2010)\end{array}$} & 62 Gy & 3,1 & 20 & 83 & RTOG & - & - & - & - & $17,0 \%$ & - & $14 \%$ & - & 3 \\
\hline & $80 \mathrm{~Gy}$ & 2 & 40 & 85 & & - & - & - & - & $16,0 \%$ & - & $11 \%$ & - & 3 \\
\hline Szignifikancia & & & & & & & & & & $N S z$ & & $N S z$ & & \\
\hline \multirow{2}{*}{$\begin{array}{l}\text { Pollack, et al. } \\
(2006)\end{array}$} & 70,2 Gy & 2,7 & 26 & 50 & RTOG & $0,0 \%$ & $0,0 \%$ & $6,0 \%$ & $0,0 \%$ & - & - & - & - & - \\
\hline & $76 \mathrm{~Gy}$ & 2 & 38 & 50 & & $2,0 \%$ & $0,0 \%$ & $8,0 \%$ & $0,0 \%$ & - & - & - & - & - \\
\hline Szignifikancia & & & & & & $N S z$ & $N S z$ & $N S z$ & $N S z$ & & & & & \\
\hline \multirow{3}{*}{$\begin{array}{l}\text { Dearnaley, } \\
\text { et al. (2012) }\end{array}$} & 57 Gy & 3 & 19 & 151 & RTOG & $0,8 \%$ & $0,0 \%$ & $7,0 \%$ & $1,3 \%$ & $4,8 \%$ & $0,7 \%$ & $4,8 \%$ & $0,7 \%$ & 2 \\
\hline & $60 \mathrm{~Gy}$ & 3 & 20 & 153 & & $2,3 \%$ & $0,0 \%$ & $7,6 \%$ & $0,0 \%$ & $6,9 \%$ & $0,7 \%$ & $9,0 \%$ & $4,2 \%$ & 2 \\
\hline & 74 Gy & 2 & 37 & 153 & & $2,3 \%$ & $0,0 \%$ & $9,0 \%$ & $0,7 \%$ & $7,6 \%$ & $0,0 \%$ & $3,5 \%$ & $1,4 \%$ & 2 \\
\hline Szignifikancia & & & & & & $N S z$ & $N S z$ & $N S z$ & $N S z$ & $N S z$ & $N S z$ & $N S z$ & $N S z$ & \\
\hline \multirow{2}{*}{$\begin{array}{l}\text { Pollack, et al. } \\
(2013)\end{array}$} & 70,2 Gy & 2,7 & 26 & 151 & RTOG & - & - & - & - & $16,1 \%$ & - & $21,5 \%$ & - & 5 \\
\hline & $78 \mathrm{~Gy}$ & 2 & 36 & 152 & & - & - & - & - & $22,5 \%$ & - & $13,4 \%$ & - & 5 \\
\hline Szignifikancia & & & & & & & & & & $N S z$ & & $N S z$ & & \\
\hline \multirow{2}{*}{$\begin{array}{l}\text { Hoffman, } \\
\text { et al. }(2014)\end{array}$} & 72 Gy & 2,4 & 30 & 102 & RTOG & - & - & - & - & $10,0 \%$ & $2,0 \%$ & $15,8 \%$ & $0,0 \%$ & 5 \\
\hline & 75,6 Gy & 1,8 & 42 & 102 & & - & - & - & - & $5,1 \%$ & $1,0 \%$ & $16,5 \%$ & $1,0 \%$ & 5 \\
\hline szignifikancia & & & & & & & & & & $N S z$ & $N S z$ & $N S z$ & $N S z$ & \\
\hline
\end{tabular}

$\mathrm{GI}=$ gastrointestinalis toxicitás; $\mathrm{Gr}=$ grade; $\mathrm{GU}=$ urogenitalis toxicitás; Gy = Gray; NA = nincs adat; NSz = nem szignifikáns; RTOG = Radiation Therapy Oncology Group.

\section{Hagyományos dózisú 3DCRT vs. magas sugárdózisú IMRT}

Négy olyan közleményt azonosítottunk, amelyek a hagyományos dózisú 3DCRT-t és a magas dózisú IMRT sugártoxicitását vetették össze [34-37] (1. táblázat).

\section{Akut és késői gastrointestinalis toxicitás (hagyomá- nyos vs. magas sugárdózis)}

Doležel [34] adatai alapján mérsékelt (grade 2) akut gastrointestinalis toxicitás kisebb valószínúséggel alakult ki az IMRT-vel kezel ágon (14\%), mint a 3DCRT-vel kezelt csoport esetében (35\%) annak ellenére, hogy az IMRT-vel kezelt betegek magasabb sugárdózist kaptak (82 Gy) a 3DCRT-csoporthoz képest (74 Gy). Súlyos (grade $\geq 3$ ) toxicitás egy beteg esetében sem alakult ki egyik csoportban sem. Vora [36] vizsgálatában valamivel nagyobb arányban fordult elö akut gastrointestinalis toxicitás, az IMRT-vel végzett besugárzás azonban itt is kedvezőbb értéket mutatott (IMRT: 50\%, 3DCRT: 54\%) a magasabb dózis ellenére (IMRT: 75,6 Gy, 3DCRT: $68,4 \mathrm{~Gy}$ ). Súlyos toxicitás kialakulása ebben a vizsgálatban sem volt jellemző. Zelefsky [37] jóval kisebb arányú akut gastrointestinalis toxicitást mért, aminek hátterében a mérési módszerben megjelenő különbség állhat. Zelefsky [37] az NCI-CTC v3.0 szerinti gradálást használta, míg az előző két tanulmány az RTOG-rendszerrel határozta meg az adatokat. Zelefsky [37] vizsgálatában az IMRT-ágon 81 Gy dózis mellett 3\%-ban, míg a 3DCRT-ágon 66-75,6 Gy közötti sugárdózissal csupán 1\%-ban fordult elő mérsékelt toxicitás. Súlyos toxicitás nem alakult ki egyik csoportban sem. A klinikai vizsgálatok adatainak metaanalízise alapján megállapítható, hogy az akut gastrointestinalis toxicitás kialakulásának kockázata közel azonos a két csoportban (random hatás, RR 1,02, 95\% CI 0,47-2,19), az eltérés nem szignifikáns $(\mathrm{p}=0,97)$. Az adatok ugyanakkor rendkívül nagy heterogenitást mutatnak $\left(\mathrm{I}^{2}=88 \%\right)$. A sugárkezelést követően később kialakuló gastrointestinalis mellékhatások esetében, hasonlóan az akut gastrointestinalis toxicitásokhoz, a vizsgált négy közleményből három [34, 35, 37] esetében a magasabb dózis ellenére az IMRT-technika alkalmazásával alacsonyabb arányban fordult elő késői toxicitás. Doležel [34] esetében az IMRT-ágon 21\%-ban, míg a 3DCRT-ágon 32\%-ban fordult elő mérsékelt vagy súlyos urigenitalis toxicitás. A Kirichenko [35] által végzett vizsgálatban ez az arány 6\%-ot (IMRT) és 10\%-ot (3DCRT) tett ki, míg Zelefsky [37] elemzésében 5\%-ot 
(IMRT) és 13\%-ot (3DCRT). Az eltérések statisztikailag szignifikánsak voltak Kirichenko [35] $(\mathrm{p}=0,009)$ és $Z e^{-}$ lefsky [37] $(\mathrm{p}<0,001)$ vizsgálatában. Egyedül Vora [36] vizsgálata mutatott fordított irányú eltérést, az IMRT esetén 24\%-ban, míg a 3DCRT-kezelés során 16\%-ban alakult ki késői mérsékelt vagy súlyos toxicitás. Az eltérés azonban ebben az esetben sem volt szignifikáns. Súlyos toxicitás a magas sugárdózis alkalmazása esetén is csak ritka esetben (0-5\%-ban) fordult elő a vizsgált tanulmányokban. A késői gastrointestinalis toxicitások vonatkozásában az adatok erôs heterogenitása mellett $\left(\mathrm{I}^{2}=88 \%\right)$ nem állapítható meg egyértelmúen $(\mathrm{p}=0,17)$, hogy a mérsékelt vagy súlyos gastrointestinalis mellékhatások kialakulásának kockázatában (random hatás, RR 0,67, 95\% CI 0,37-1,20) lenne érdemi eltérés (2. ábra).

Akut és késői urogenitalis toxicitás (hagyományos vs. magas sugárdózis)

Doležel [34] vizsgálatában a mérsékelt vagy súlyos urogenitalis toxicitás (GU grade $\geq 2$ ) az IMRT-ágon átlag 33\%-ban alakult ki, míg a 3DCRT esetében 27\%-ban. Vora [36] vizsgálatában a magas dózisú IMRT-t alkalmazva 49\%-ban, míg az alacsonyabb dózisú 3DCRT-nél 40\%-ban fordult elő mérsékelt vagy súlyos urogenitalis toxicitás. Zelefsky [37] vizsgálatában is hasonló eltérés mutatkozott: a magasabb dózis (IMRT) következtében 37\%-ban alakult ki toxicitás, míg az alacsonyabb dózis (3DCRT) mellett mindössze 22\%-ban, súlyos toxicitás (grade $\geq 3$ ) azonban nem alakult ki.

$\mathrm{Az}$ urogenitalis mellékhatások vonatkozásában a magasabb sugárdózis következtében a kezelést követően az IMRT használatával nagyobb arányban alakult ki mérsékelt urogenitalis toxicitás (random hatás, RR 1,39, 95\% CI 1,09-1,78, p = 0,008). Az adatok azonban ebben az esetben is erős heterogenitást mutatnak $\left(\mathrm{I}^{2}=68 \%\right)$. A súlyos urogenitalis toxicitás kialakulásának kockázatában nincs eltérés (random hatás, RR 1,08, 95\% CI 0,32$\left.3,68, \mathrm{p}=0,9, \mathrm{I}^{2}=61 \%\right)$.

Doležel [34] vizsgálatában az IMRT-ágon a késői urogenitalis toxicitás kialakulásának aránya $14 \%$ volt, míg a 3DCRT esetében szintén 14\%. Kirichenko [35] közleményében $6 \%$, illetve $8 \%$ volt a toxicitás kialakulásának aránya a 3DCRT- és IMRT-kezelés esetén. Vora [36] elemzésében az IMRT vonatkozásában 28\%, míg a 3DCRT esetében 21\%-ban alakult ki mérsékelt vagy súlyos urogenitalis toxicitás. Mindhárom vizsgálat esetében azonban az eltérés nem volt szignifikáns. Egyedül a Zelefsky [37] által közölt adatok vonatkozásában volt statisztikai értelemben véve is szignifikáns különbség, ahol az IMRT esetében $20 \%$, míg a 3DCRT vonatkozásában $12 \%$ volt a mérsékelt vagy súlyos késői urogenitalis toxicitás kialakulásának aránya.

A késői mérsékelt urogenitalis mellékhatás hasonlóan az akut urogenitalis toxicitáshoz, gyakrabban fejlődött ki a magasabb sugárdózissal történő kezelés esetén (random hatás, RR 1,48, 95\% CI 1,26-1,75). A vizsgálat alapján az eltérés szignifikáns $(\mathrm{p}<0,00001)$ és az adatok homogének $\left(\mathrm{I}^{2}=0 \%\right)$. A súlyos toxicitások kialakulásában ugyanakkor nincs eltérés (random hatás, RR 0,99, 95\% CI 0,66-1,48, $\mathrm{p}=0,8, \mathrm{I}^{2}=0 \%$ ) (3. ábra).

\section{Normofrakcionált vs. hipofrakcionált IMRT}

A hipofrakcionált, magas dózisú IMRT-vel történő sugárkezelés mellékhatásairól viszonylag kevés irodalom érhető el, amelyek ugyanakkor alacsony (50 és 150 közötti) esetszámúak. Két RCT-t azonosítottunk, amely közölt adatokat az akut toxicitásokról. Dearnaley [38] és Pollack [39] közleményén kívül három további RCT Arcangeli [40], Pollack [41], Hoffman [42] - foglalkozott a késői toxicitások arányaival (2. táblázat).

Akut és késői gastrointestinalis toxicitás (normofrakcionálás vs. hipofrakcionálás)

Dearnaley [38] esetében a normál- és a hipofrakcionálású csoportban $2,3 \%$, illetve átlag 1,6\%-ban fordult elő akut toxicitás. Pollack [39] esetében az előfordulás aránya fordított volt, a normálfrakcionálású csoportban az esetek 8\%-ánál, míg a hipofrakcionált csoportban 2\%-ban jelentkeztek heveny tünetek. Súlyos toxicitás egyik vizsgálatban sem fordult elő. A két vizsgálat eredményét alapul véve az akut gastrointestinalis toxicitás kockázatának kialakulásában nincs lényegi különbség a két csoport között (random hatás, RR 1,25, 95\% CI 0,36-4,33, p = $0,73)$. Az adatok magas heterogenitásúak $\left(\mathrm{I}^{2}=53 \%\right)$.

Késői gastrointestinalis mellékhatás a normál- és hipofrakcionált csoportban Arcangeli [40] elemzésében 16\%, illetve 17\%-ban alakult ki. Dearnaley [38] vizsgálatában a normo- és hipofrakcionált kezelésben részesült betegek 7,8 és 5,9\%-ában alakult ki mérsékelt vagy súlyos gastrointestinalis toxicitás. A Hoffman [42] által publikált RCT-ben ez az arány 5,1\% és $10 \%$, míg a Pollack [41] által 2013-ban publikált klinikai vizsgálati eredmények alapján 22,5\% és 18,1\%-ban fejlődött ki mérsékelt gastrointestinalis mellékhatás a hagyományos és hipofrakcionált módon sugárkezelt vizsgálati csoportokban.

A vizsgált közlemények metaanalízise alapján a késői gastrointestinalis toxicitás kialakulásának kockázata a hipofrakcionálás alkalmazása esetén közel megegyezik a normálfrakcionálású kezelés esetén felmerülő kockázattal (random hatás, RR 0,91, 95\% CI 0,66-1,25). A két besugárzási módszer kockázata közötti eltérés nem tekinthetô szignifikánsnak $(\mathrm{p}=0,55)$. Az adatok nem mutatnak heterogenitást $\left(\mathrm{I}^{2}=0 \%\right)$ (4. ábra).

Akut és késői urogenitalis toxicitás (normofrakcionálás vs. hipofrakcionálás)

$\mathrm{Az}$ akut urogenitalis toxicitások esetében a két vizsgálatot alapul véve nyilvánvalóbb kép rajzolódik ki. A normál- és hipofrakcionált csoportban Dearnaley [38] vizsgálatában 9, illetve 8\%-ban, míg Pollack [39] elemzésében 56 és 48\%-ban alakult ki mérsékelt urogenitalis mellékhatás. Súlyos toxicitás nem alakult ki. A két RCT-t figye- 


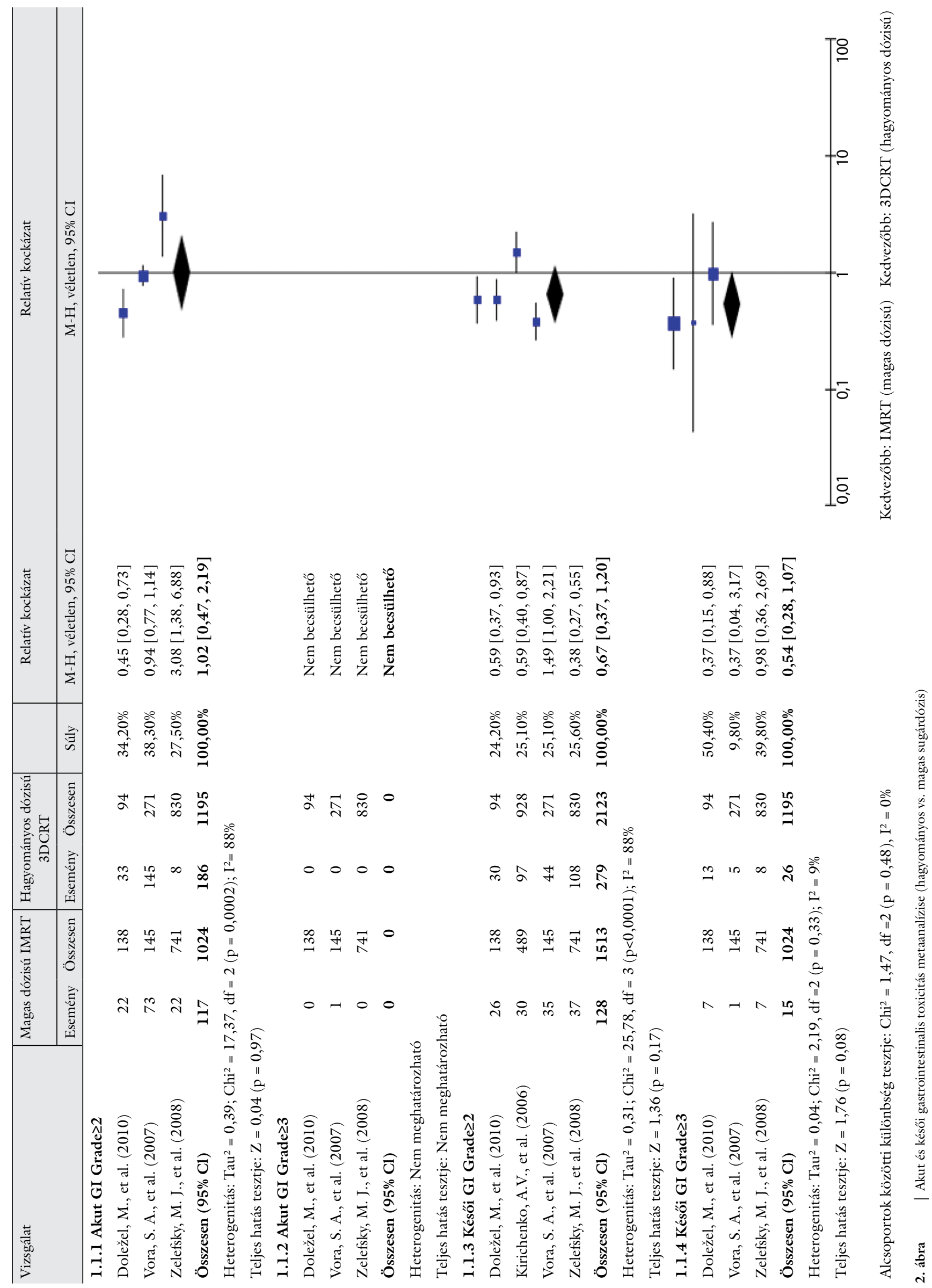




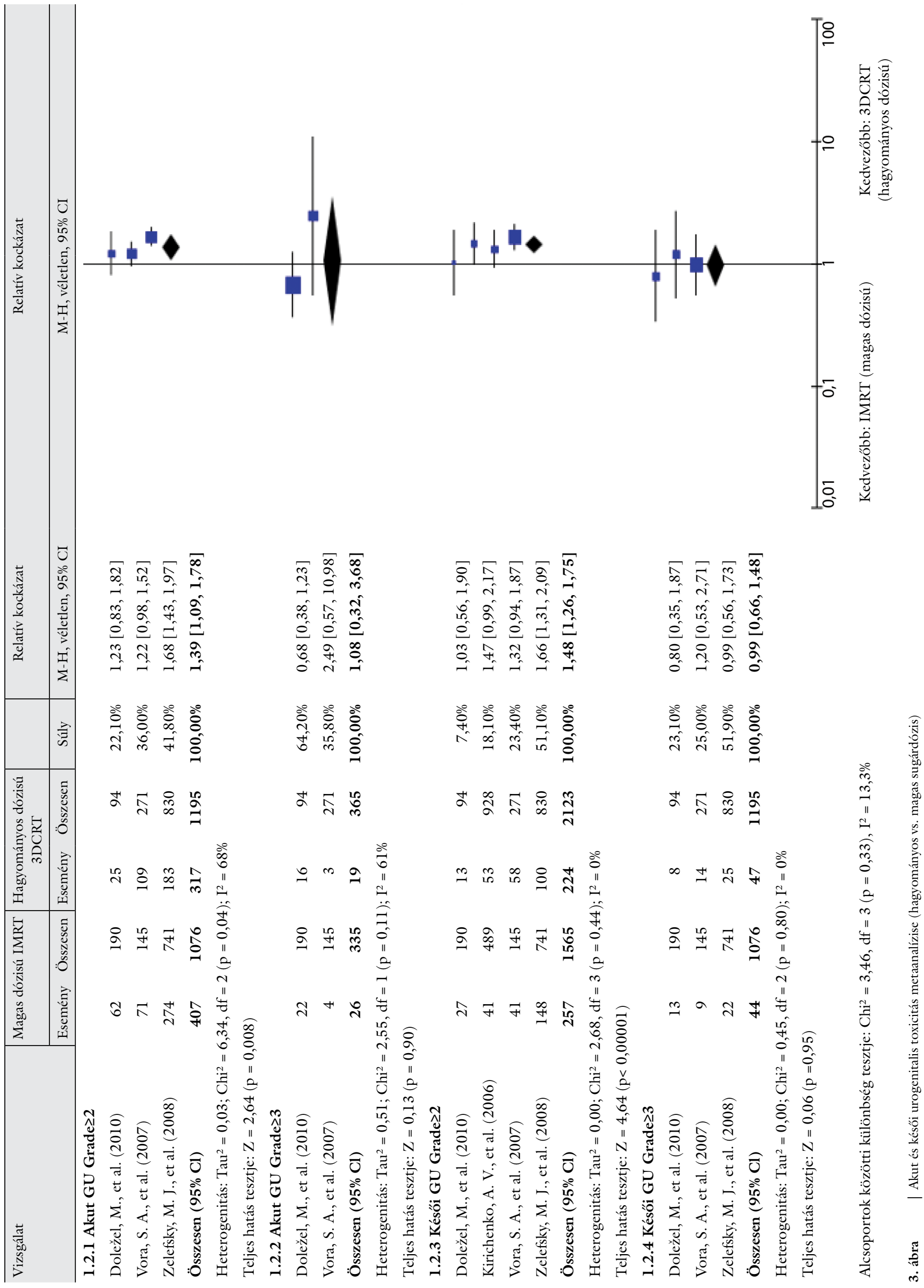



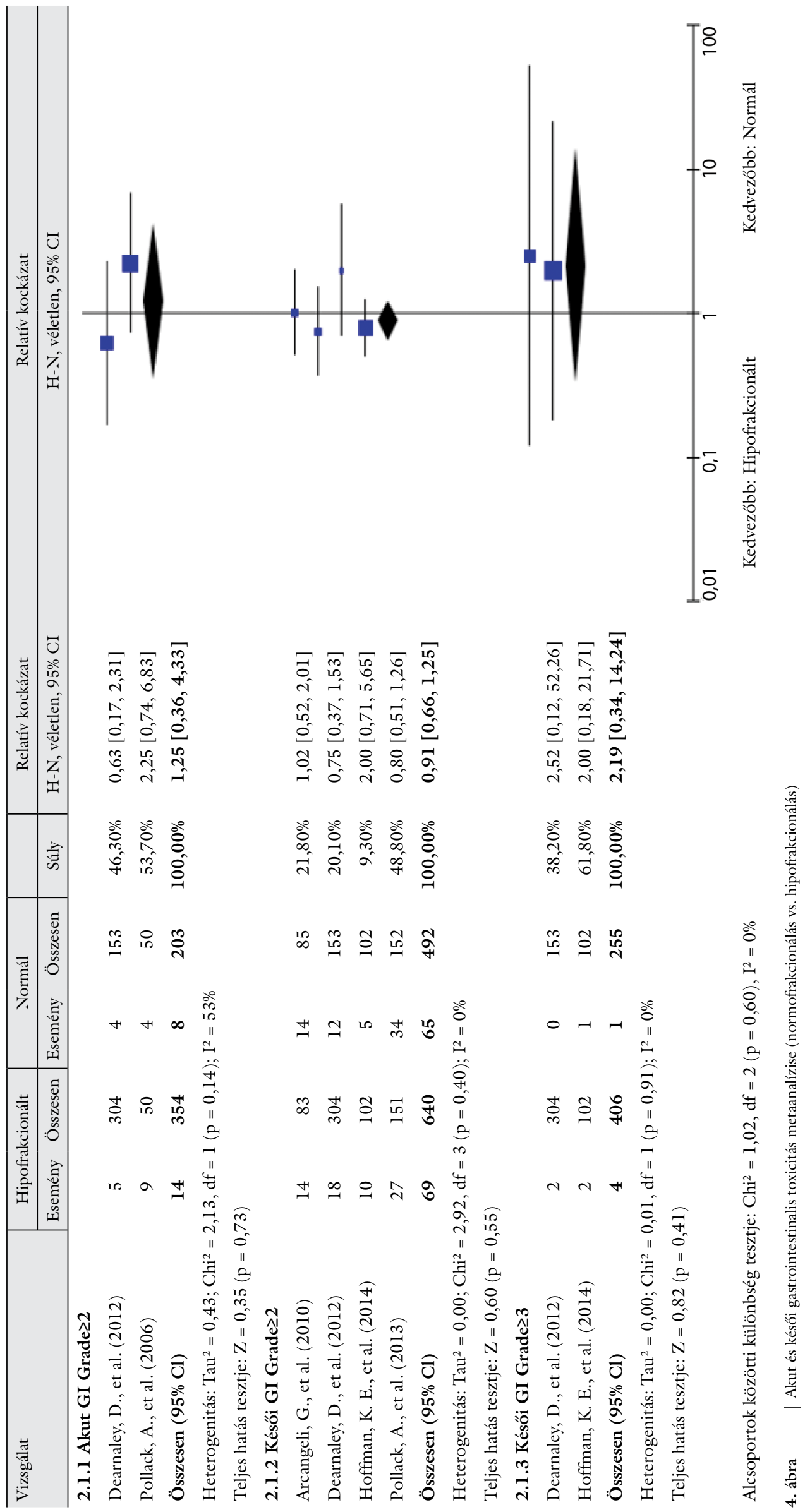


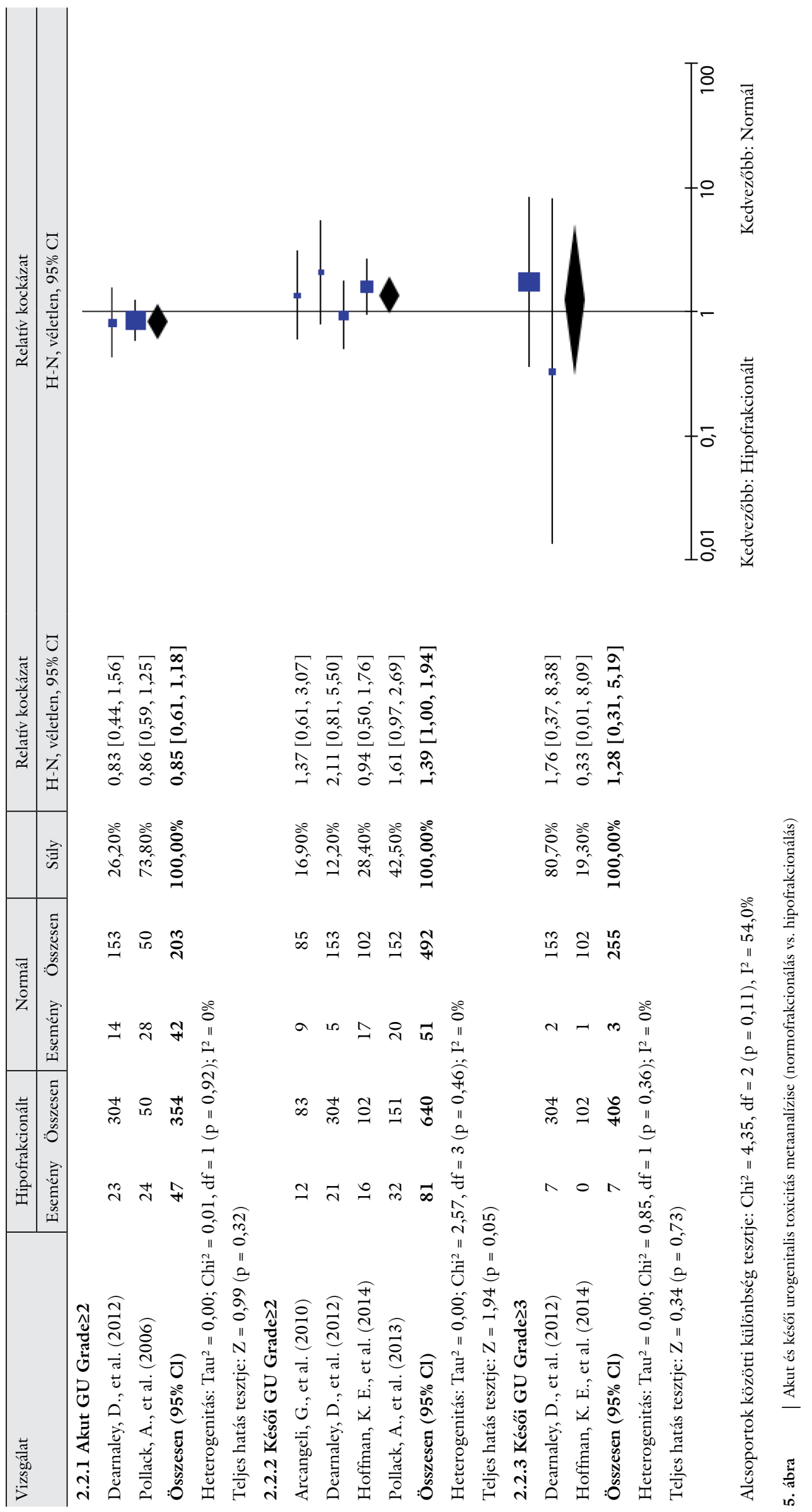


lembe véve az akut urogenitalis toxicitás kialakulásának kockázatában sincs érdemi különbség (random hatás, RR 0,85, 95\% CI 0,61-1,18, p=0,32). Az adatok ebben az esetben homogének $\left(\mathrm{I}^{2}=0 \%\right)$.

Arcangeli [40] vizsgálatában a késői urogenitalis mellékhatás aránya a normálfrakcionálás esetén $11 \%$, míg a hipofrakcionált csoportban $14 \%$ volt. Dearnaley [38] közleményében $3,3 \%$, illetve $6,9 \%$ volt a toxicitás kialakulásának aránya a két csoportban. Vizsgálatában a normálfrakcionálással kezelt betegek 1,4\%-ában, míg a hipofrakcionálás esetén 2,3\%-ban alakult ki súlyosabb toxicitás. Hoffman [42] elemzésében a normálfrakcionálású IMRT-kezelés esetében 16,5\%-ban, míg a hipofrakcionálású IMRT-kezelés esetén 15,8\%-ban alakult ki mérsékelt vagy súlyos urogenitalis toxicitás. Pollack [41] közleményében a hagyományos frakcionálású ágon 13,4\%-ban, míg hipofrakcionálás esetén 21,5\%-ban alakult ki késői urogenitalis toxicitás.

A vizsgált közlemények adatai alapján tehát hipofrakcionálás alkalmazása esetén magasabb a késői mérsékelt vagy súlyos urogenitalis toxicitás kialakulásának kockázata a normálfrakcionálású IMRT-besugárzáshoz képest (random hatás, RR 1,39, 95\% CI 1,00-1,94, p = 0,05). $\mathrm{Az}$ adatok ebben az esetben is homogének $\left(\mathrm{I}^{2}=0 \%\right)$ (5. ábra).

\section{Megbeszélés}

A magasabb sugárdózis hosszabb távon javítja a progressziómentes túlélés esélyeit. Viani [5] hat randomizált vizsgálat eredményeit összegezve elemezte a biokémiai progresszió valószínúségét alacsony, közepes és magas kockázatú lokalizált prosztatarákos betegeknél. A teljes populációra vonatkozó esélyhányados 0,60 (99\% CI 0,47-0,76, p<0,0001), ami szignifikáns kockázatcsökkenést jelent a magas dózisú ágon kezelt betegek vonatkozásában. Viani [5] metaanalízise egyúttal azt is megállapította, hogy az emelt dózisú sugárterápia alkalmazása esetén a mérsékelt vagy annál súlyosabb késői gastrointestinalis sugártoxicitás esélyhányadosa 1,58 (99\% CI 1,24-2, p<0,0001), míg a késői urogenitalis toxicitás esélyhányadosa $1,2(99 \% \mathrm{CI} 0,93-1,54, \mathrm{p}=0,054)$. Viani [5] elemzésében ugyanakkor nem vizsgálta, hogy csökkenthető-e a mellékhatások kialakulásának kockázata intenzitásmodulált és képvezérelt besugárzási technika alkalmazásával.

Obri [27] metaanalízise szerint a magasabb dózis (>74 Gy) IMRT-vel történő leadása esetén jelentősen, 15,4\%kal $(95 \%$ CI $-26,7 \%,-4,2 \%, p=0,011)$ csökken a mérsékelt vagy súlyos késői gastrointestinalis toxicitás kialakulásának valószínúsége a szintén magasabb dózisú 3DCRT alkalmazásához képest. A késői grade $\geq 2$ urogenitalis toxicitás vonatkozásában az IMRT szintén kedvezőbb eredményt mutat: $-3,1 \%$ (95\% CI $-16,9,10,6 \%, \mathrm{p}=$ $0,629)$, az eltérés azonban nem szignifikáns. A kedvező tumorkontroll elérése érdekében alkalmazott magasabb dózis esetén tehát az IMRT biztonságosabb, mint a
3DCRT. Obri [27] ugyanakkor nem a hagyományos dózisú 3DCRT-vel vetette össze a magasabb dózisú IMRT-t, elemzése így arra a kérdésre nem ad egyértelmú választ, hogy a magas dózis révén elérhető kedvezőbb tumorkontroll elérése érdekében milyen „árat” kell fizetni a mellékhatások tekintetében a hagyományos dózisú 3DCRT-hez képest.

A sugártoxicitás valószínúségét tehát mind a dózis nagysága, mind a besugárzási technika befolyásolja, ezért az általunk végzett metaanalízis arra fókuszált, hogy a jelenlegi magyar gyakorlatban a prosztatadaganatos betegek kezelésére alkalmazott hagyományos dózisú 3DCRT-kezeléshez képest a magasabb dózisú IMRT-re történő átállás milyen kockázattal jár.

$\mathrm{Az}$ elemzésben figyelembe vett klinikai vizsgálatok alapján a súlyos (grade $\geq 3$ ), kórházi kezelést igénylő urogenitalis és gastrointestinalis toxicitás kialakulásának előfordulása alacsony volt. A magasabb sugárdózis alkalmazása ellenére az IMRT-vel kezelt betegek esetében ritkábban jelentkeztek az akut és krónikus gastrointestinalis mellékhatások, ez az eltérés ugyanakkor statisztikai értelemben véve nem volt szignifikáns. Az elemzésbe bevont vizsgálatokban a magasabb dózis alkalmazása ugyanakkor egyértelműen növelte a sugárterápiát követően és a később kifejlődő urogenitalis toxicitások kialakulását. Ennek a valószínúsíthető oka az, hogy a fejlettebb technológia használata esetén jelentősen lehet csökkenteni a környező bélstruktúrák, elsősorban a végbél dózisterhelését, ugyanakkor ez a hatás nem érvényesíthető az intraprostaticus elhelyezkedésű húgycső vagy a prosztatának fekvő hólyagnyak esetében.

A hipofrakcionálással történő sugárkezelés hatásosságát vizsgáló RCT-k [4l-44] kedvezóbb progressziómentes túlélési adatokat közölnek, az eltérés azonban csak a magas kockázatú lokalizált prosztatarákos betegek kezelése vonatkozásában szignifikáns. A hipofrakcionálással vélhetően kedvezőbb hatásosság érhető el a tumorkontroll területén, ugyanakkor további vizsgálatok szükségesek ennek bizonyító erejü alátámasztására. A hipofrakcionált IMRT akut sugártoxicitásáról mindössze két közleményben találtunk összehasonlító adatot, amelyek elemzése alapján nem lehet nyilvánvaló következtetést levonni, mivel az eltérés sem a gastrointestinalis, sem az urogenitalis toxicitás vonatkozásában nem volt szignifikáns. A hipofrakcionálás késői gastrointestinalis toxicitásra gyakorolt hatása sem egyértelmü, a klinikai vizsgálatok eredménye ebben eltérést mutat, így további RCT-k, illetve hosszabb utánkövetés szükséges ahhoz, hogy erről pontosabb adatok álljanak majd rendelkezésre. Egyedül a késői urogenitalis toxicitás esetében mutatható ki, hogy az egyszeri nagyobb sugárdózisok alkalmazása növeli a mellékhatás kialakulásának kockázatát. Ki kell azonban emelni, hogy súlyos toxicitás a vizsgált RCT-kben hipofrakcionálás következményeként csak kis számban fordult elő, miközben a daganat kiújulásának valószínúségét egyértelmúen csökkenti. A hipofrakcionálás alkalmazásának persze van egy alapvető, a beveze- 
tésben már említett sugárbiológiai oka is, hiszen a prostataadenocarcinoma típusosan a normálfrakcionálásra kevéssé érzékeny daganatos szövetek közé tartozik (mint több más mirigysejtes rák is). Ez azt jelenti, hogy az egyszeri nagyobb dózisok alkalmazása esetén komolyabb sugárterápiás effektus várható, még akár a teljes dózis csökkentése mellett is. Persze ez a sugárbiológiai ismeret már régóta tudott, de a kétezres évekig használt technológiák nem tették lehetővé a magasabb napi dózisok alkalmazását, hiszen az okozott mellékhatások jelentősen meghaladták volna a tolerálható mértéket.

Az IMRT-vel megvalósított dóziseszkaláció javítja a progressziómentes túlélés esélyeit, miközben csökkenti a gastrointestinalis toxicitások kialakulásának kockázatát. A magasabb dózis ugyanakkor a mérsékelt urogenitalis mellékhatások előfordulását növeli, súlyosabb következményekkel járó toxicitást azonban csak kis eséllyel okoz. A magas dózisú hipofrakcionált IMRT a daganat kiújulásának valószínúségét még nagyobb eséllyel csökkenti, mint a normofrakcionált IMRT. A késői urogenitalis mellékhatások előfordulási aránya meghaladja ugyan a normálfrakcionálású csoportban jelentkező tünetek arányát, ennek mértéke azonban nem jelentős, és súlyos mellékhatás csak elvétve jelentkezik. A hipofrakcionálás szerepének tisztázására és alkalmazásának kiterjesztésére további mérések és elemzések szükségesek, amelyek figyelembe veszik a rövidebb ellátási időből származó előnyöket a betegek számára, illetve az alacsonyabb időráfordításból származó lehetséges megtakarításokat az egészségügyi szolgáltatók körében.

Anyagi támogatás: A közlemény megírása anyagi támogatásban nem részesült.

Szerzôi munkamegosztás: Z. A. T., M. L., B. I.: A vizsgálat tervezése és lefolytatása. Z. A. T., K. Z., L. Sz.: Statisztikai elemzések. Z. A. T., M. L., E. D., B. I.: Irodalomkutatás. M. L., Z. A. T., B. I., L. Sz.: A kézirat megszövegezése. A cikk végleges változatát valamennyi szerző elolvasta és jóváhagyta.

Érdekeltségek: A szerző́knek nincsenek érdekeltségeik.

\section{Irodalom}

[1] World Health Organization, International Agency for Research on Cancer: GLOBOCAN 2012: Estimated Cancer Incidence, Mortality and Prevalence Worldwide 2012 (2015). www.globocan.iarc.fr/Pages/fact_sheets_cancer.aspx

[2] American Cancer Society: Cancer Facts \& Figures 2012. Am. Cancer Soc., 2012. www.cancer.org/Research/CancerFactsFigures/CancerFactsFigures/cancer-facts-figures-2012

[3] International Agency for Research on Cancer: Estimated incidence, mortality \& prevalence, 2012. www.eco.iarc.fr/eucan/CancerOne.aspx? Cancer $=29 \&$ Gender $=1$

[4] National Institute of Oncology: National Cancer Registry. Statistics of Cancer Registry. [Országos Onkológiai Intézet: Nemzeti Rákregiszter - Rákregiszter Statisztika.] http://www.onkol.hu/ hu/rakregiszter-statisztika [Hungarian]
[5] Viani, G. A., Stefano, E. J., Afonso, S. L.: Higher-than-conventional radiation doses in localized prostate cancer treatment: A meta-analysis of randomized, controlled trials. Int. J. Radiat. Oncol. Biol. Phys., 2009, 74(5), 1405-1418.

[6] Horwich, A., Hugosson, J., De Reijke, T., et al.: Prostate cancer: ESMO consensus conference guidelines 2012. Ann. Oncol., 2013, 24(5), 1141-1162.

[7] Heidenreich, A., Bastian, P. J., Bellmunt, J., et al.: EAU guidelines on prostate cancer. Part 1: Screening, diagnosis, and local treatment with curative intent - Update 2013. Eur. Urol., 2014, 65(1), 124-137.

[8] Irani, J., Brown, C. T., van der Meulen, J., et al.: A review of guidelines on benign prostatic hyperplasia and lower urinary tract symptoms: are all guidelines the same? BJU Int., 2003, 92(9), 937-942.

[9] National Comprehensive Cancer Network: Prostate Cancer Version 2.2014. NCCN Guideline, 2014. www.tri-kobe.org/nccn/ guideline/urological/english/prostate.pdf

[10] Szappanos, S., Farkas, R., Lócsei, Z., et al.: New methods in the treatment of localized prostate cancer: usage of dynamic arc therapy and $\mathrm{kV}$ cone-beam CT positioning. [Új módszerek a prosztatadaganatok sugárkezelésében: dinamikus ívbesugárzás és kilovoltos „cone-beam” komputertomográfiás ellenőrzés.] Orv. Hetil., 2014, 155(32), 1265-1272. [Hungarian]

[11] Zemplényi, A. T., Kaló, Z., Kovács, G., et al.: Cost-effectiveness analysis of intensity-modulated radiation therapy with normal and hypofractionated schemes for the treatment of localised prostate cancer. Eur. J. Cancer Care, 2016 Jan 19. doi: 10.1111/ ecc. 12430 [Epub ahead of print]

[12] Zemplényi, A. T., Mangel, L., Kaló, Z., et al.: A microcosting study of radiation therapy of localized prostate cancer. [A prosztatadaganatos betegek sugárterápiájának mikroköltség-számítása.] Orv. Hetil., 2016, 157(12), 461-468. [Hungarian]

[13] Lennernös, B., Nilsson, S., Levitt, S.: Hypofractionation for radiotherapy of prostate cancer using a low alfa/beta ratio - possible reasons for concerns? An example of five dimensional radiotherapy. Acta Oncol., 2011, 50(Suppl. 1), 111-115.

[14] Moraes, F. Y., Siqueira, G. M., Abreu, C. E., et al.: Hypofractioned radiotherapy in prostate cancer: is it the next step? Expert Rev. Anticancer Ther., 2014, 14(11), 1271-1276.

[15] Ritter, M.: Rationale, conduct, and outcome using hypofractionated radiotherapy in prostate cancer. Semin. Radiat. Oncol., 2008, 18(4), 249-256.

[16] Spyropoulou, D., Kardamakis, D.: Review of hypofractionated radiotherapy for prostate cancer. ISRN Oncol., 2012, 2012, 410892.

[17] Yamazaki, H., Nakamura, S., Suzuki, G., et al.: Hypofractionated radiotherapy for localized prostate cancer: A challenging accelerated hypofractionated radiotherapy. Anticancer Res., 2015, 35(10), 5167-5177.

[18] Zemplényi, A., Kaló, Z., Boncz, I., et al.: A microcosting study of radiation therapy in localized prostate cancer patients in a Hungarian tertiary oncology center. Value Health, 2015, 18(7), A354.

[19] Inotai, A., Kaló, Z., Nagyjánosi, L.: The hierarchy of research evidence. In: Kaló, Z., Inotai, A., Nagyjánosi, L. (eds.): Health economics glossary I. Economic evaluation of health technologies. [Tudományos bizonyítékok hierarchiája. In: Kaló, Z., Inotai, A., Nagyjánosi, L. (szerk.): Egészség-gazdaságtani fogalomtár I. Egészségügyi technológiák gazdasági elemzése.] Professional Publishing Hungary Kft., Budapest, 2009. [Hungarian]

[20] The Nordic Cochrane Centre: Review Manager (RevMan) Version 5.3 (2014). www.tech.cochrane.org/revman

[21] Parmar, M. K., Torri, V., Stewart, L.: Extracting summary statistics to perform meta-analyses of the published literature for survival endpoints. Stat. Med., 1998, 17(24), 2815-2834. 
[22] Higgins, J. P., Thompson, S. G., Deeks, J. J., et al.: Measuring inconsistency in meta-analyses. BMJ, 2003, 327(7414), 557-560.

[23] Crombie, I. K., Davies, H. T.: What is meta-analysis? Evid. Based Med., 2013, 16(1), 3-4.

[24] Bauman, G., Rumble, R. B., Chen, J., et al.: Intensity-modulated radiotherapy in the treatment of prostate cancer. Clin. Oncol., 2012, 24(7), 461-473.

[25] Hummel, S., Simpson, E. L., Hemingway, P., et al.: Intensity-modulated radiotherapy for the treatment of prostate cancer: a systematic review and economic evaluation. Health Technol. Assess., 2010, 14(47), 1-108, iii-iv.

[26] Hummel, S. R., Stevenson, M. D., Simpson, E. L., et al.: A model of the cost-effectiveness of intensity-modulated radiotherapy in comparison with three-dimensional conformal radiotherapy for the treatment of localised prostate cancer. Clin. Oncol., 2012, 24(10), el59-el67.

[27] Ohri, N., Dicker, A. P., Showalter, T. N.: Late toxicity rates following definitive radiotherapy for prostate cancer. Can. J. Urol., 2012, 19(4), 6373-6380.

[28] Wilt, T. J., MacDonald, R., Rutks, I., et al.: Systematic review: comparative effectiveness and harms of treatments for clinically localized prostate cancer. Ann. Intern. Med., 2008, 148(6), $435-448$.

[29] Yong, J. H., Beca, J., McGowan, T., et al.: Cost-effectiveness of intensity-modulated radiotherapy in prostate cancer. Clin. Oncol., 2012, 24(7), 521-531.

[30] Botrel, T. E., Clark, O., Pompeo, A. C., et al.: Hypofractionated external-beam radiation therapy (HEBRT) versus conventional external-beam radiation (CEBRT) in patients with localized prostate cancer: a systematic review and meta-analysis. Core Evid., 2013, 8, 1-13.

[31] Koontz, B. F., Bossi, A., Cozzarini, C., et al.: A systematic review of hypofractionation for primary management of prostate cancer Eur. Urol., 2015, 68(4), 683-691.

[32] Zaorsky, N. G., Ohri, N., Showalter, T. N., et al.: Systematic review of hypofractionated radiation therapy for prostate cancer. Cancer Treat. Rev., 2013, 39(7), 726-736.

[33] Tree, A. C., Khoo, V. S., van As, N. J., et al.: Is biochemical relapse-free survival after profoundly hypofractionated radiotherapy consistent with current radiobiological models? Clin. Oncol., 2014, 26(4), 216-229.

[34] Doležel, M., Odrazka, K., Vaculikova, M., et al.: Dose escalation in prostate radiotherapy up to 82 Gy using simultaneous integrated boost. Direct comparison of acute and late toxicity with 3D-CRT 74 Gy and IMRT 78 Gy. Strahlenther. Onkol., 2010, $186(4), 197-202$

[35] Kirichenko, A. V., Ruth, K., Horwitz, E. M., et al.: Intensity modulated radiation therapy for prostate cancer: preliminary results on treatment morbidity compared to 3-D conformal radiation therapy. Int. J. Radiat. Oncol. Biol. Phys., 2006, 66(3), S326.

[36] Vora, S. A., Wong, W. W., Schild, S. E., et al.: Analysis of biochemical control and prognostic factors in patients treated with either low-dose three-dimensional conformal radiation therapy or high-dose intensity-modulated radiotherapy for localized prostate cancer. Int. J. Radiat. Oncol. Biol. Phys., 2007, 68(4), 1053-1058.

[37] Zelefsky, M. J., Levin, E. J., Hunt, M., et al.: Incidence of late rectal and urinary toxicities after three-dimensional conformal radiotherapy and intensity-modulated radiotherapy for localized prostate cancer. Int. J. Radiat. Oncol. Biol. Phys., 2008, 70(4), 1124-1129.

[38] Dearnaley, D., Syndikus, I., Sumo, G., et al.: Conventional versus hypofractionated high-dose intensity-modulated radiotherapy for prostate cancer: Preliminary safety results from the CHHiP randomised controlled trial. Lancet Oncol., 2012, 13(1), 43-54.

[39] Pollack, A., Hanlon, A. L., Horwitz, E. M., et al.: Dosimetry and preliminary acute toxicity in the first 100 men treated for prostate cancer on a randomized hypofractionation dose escalation trial. Int. J. Radiat. Oncol. Biol. Phys., 2006, 64(2), 518-526.

[40] Arcangeli, G., Saracino, B., Gomellini, S., et al.: A prospective phase III randomized trial of hypofractionation versus conventional fractionation in patients with high-risk prostate cancer. Int. J. Radiat. Oncol. Biol. Phys., 2010, 78(1), 11-18.

[41] Pollack, A., Walker, G., Horwitz, E. M., et al.: Randomized trial of hypofractionated external-beam radiotherapy for prostate cancer. J. Clin. Oncol., 2013, 31(31), 3860-3868.

[42] Hoffman, K. E., Voong, K. R., Pugh, T. J., et al.: Risk of late toxicity in men receiving dose-escalated hypofractionated intensity modulated prostate radiation therapy: Results from a randomized trial. Int. J. Radiat. Oncol. Biol. Phys., 2014, 88(5), 1074-1084.

[43] Arcangeli, S., Strigari, L., Gomellini, S., et al.: Updated results and patterns of failure in a randomized hypofractionation trial for high-risk prostate cancer. Int. J. Radiat. Oncol. Biol. Phys., 2012, 84(5), 1172-1178.

[44] Kuban, D. A., Nogueras-Gonzalez, G. M., Hamblin, L., et al.: Preliminary report of a randomized dose escalation trial for prostate cancer using hypofractionation. Int. J. Radiat. Oncol. Biol. Phys., 2010, 78(3), S58-S59.

(Zemplényi Antal Tamás, Pécs, Rákóczi u. 2., 7633 e-mail: zemplenyi.antal@pte.hu) 